\title{
SCREENING OF RHIZOBACTERIA FROM ONION RHIZOSPHERE CAN INDUCE SYSTEMIC RESISTANCE TO BACTERIAL LEAF BLIGHT DISEASE ON ONION PLANTS
}

\author{
Milda Ernita ${ }^{1}$, Trimurti Habazar $^{2}$, Nasrun ${ }^{3}$, Jamsari ${ }^{4}$ \\ ${ }^{1}$ Department Agrotechnology Faculty of Agriculture, Tamansiswa University, West Sumatra. Indonesia, email: \\ ${ }^{2}$ Department Plant Pest and Disease Faculty of Agriculture, Andalas University, West Sumatra. Indonesia \\ ${ }^{3}$ Researcher of Research and Development Center of Plantation, West Sumatra. Indonesia, \\ ${ }^{4}$ Department Agroecotechnology, Faculty of Agriculture, Andalas University, West Sumatra. Indonesia
}

*Corresponding author : milda.ernita@yahoo.com

Received : 14 October 2015

Accepted : 10 Desember 2015

\begin{abstract}
In modern cultivation processes indiscriminate use of pesticides and fertilizers, has led to substantial pollution of soil, air and water. So, there is an urgent need to solve the problem. Rhizobacteria are bacteria that colonize plant roots, and these bacteria are known to stimulate growth and thereby reduce incidence of plant disease by direct and indirect mechanisms. A total of 136 rhizobacteria isolates were isolated from different rhizosphere soils in central areas of production of onions in Indonesia. These isolates were screened for their capability to enhance growth and protect onions against bacterial leaf blight disease-caused by Xanthomonas axonopodis pvallii. The results showed that ten isolates can enhance growth and protect onions against bacterial leaf blight diseases. Five isolates were isolated from West Sumatra, four isolates from Java and one isolated from North Sumatra. All isolates produced indol-3-acetic acid with different concentrations. Molecular identification of ten isolates belong to Bacillus sp, Pseudomonas sp, Stenotrophomonas sp and Serratia sp.
\end{abstract}

Keywords: rhizosphere bacteria, bacterial leafblight disease, onion.

\section{INTRODUCTION}

Bacterial leaf blight disease caused by Xanthomonas axonopodis pv allii (Xaa) is one of the limiting factors of onion production. The first, symptoms of the disease were reported in Indonesia in 2001 (Habazar, 2006). Testing for the resistance to the pathogen on onion was reported Fadli (2005), and testing for capability Xaa to infect some onion species was also recorded Husna (2006). Elsewhere, the disease has been reported by Alvares et al. (1978) as a problem on onions in Hawaii. Gent and Schwartz (2005) reported varying yield losses depending on the time of infection, severity and with a range of infection from 20 to $100 \%$ under disease-favorable conditions. In Indonesia this yield loss data is not currently available.

This bacteria is difficult to control because the pathogen survives in soil, seed-borne, sprinkler, agricultural equipment and infects some genus of weeds without symptoms (Roumagnac et al, 2004; Schwartz and Gent, 2005) and a few other Allium species (Paulraj and O'Garro, 1993), although some strains are reportedly pathogenic to leguminous hosts such snap bean (Phaseolus vulgaris), lima bean (Phaseolus lunatus), soybean (Glycine max), winged bean (Psophocarpus tetragonolobus), moth bean (Vigna aconitifolia) and field pea (Pisum sativum) (Gent et al, 2005).

Management strategies are available to mitigate Xaa such as crop rotation, sanitation, using resistance varieties, copper or zinc application and biological control (Schwartz and Gent, 2007). In Indonesia the disease of HDB is a new disease, so there is a lack of information concerning control techniques. Bactericide application can control Xaa, but they can not be seen as a long-term solution because of concerns over exposure risk, health and environmental hazards, and residue persistence. 
Moreover, the frequent use of bactericide may lead to the development of tolerance in the organisms. One potential method to reduce the severity of disease caused by the pathogen is the introduction of rhizobacteria. The application of microorganisms to control diseases, which is a form of biological control, is an environment-friendly approach (Lugtenberg and Kamilova, 2009; Chakraborty et al, 2013).

Rhizobacteria are bacteria that colonize plants roots and stimulate plant growth and thereby reduce the incidence of plant diseases. These beneficial rhizobacteria are termed Plant Growth Promoting Rhizobacteria (PGPR) (Kloepper and Schroth, 1981). PGPR are a very small portion of rhizobacteria approximately 2-5\%, that promote plant growth (Van Loon and Bakker, 2003; Manoharachary and Mukerji. 2006). PGPR use one or more direct and indirect mechanisms to improve plant growth and health. These mechanisms may be sequentially or active simultaneously at different stages of plant development. Direct influence on plant growth like improvement of nutrient uptake by phosphate-solubization, chelate iron or N2 fixation and phytohormone production such as indol-3- acetic acid. Indirect mechanisms involve the biological control of plant pathogens and deleterious microbes through the production of antibiotic litic enzymes, hydrogen cyanide, catalase and competition for nutrient and space (Nelson, 2004 ; Khan, 2006).

The application of indigenous rhizobacteria against endemic plant disease by enhancing plant resistance aganst bacterial pathogens, have more potential for future development. Indigenous rhizobacteria better able to adapt than the introduce rhizobacteria. Brimecombe et al, (2001) reported that rhizobacteria application success is determined by their ability to colonize plant roots. Several research have examined the possibilities of using rhizobacteria like Pseudomonas sp, Bacillus sp, Stenotrophomonas sp and Serratia sp and other rhizobacteria for inducing systemic resistance in plant to fungal, bacterial and viral diseases (Sutariati and Wahab 2010; Taufik et al, 2010), and it can also be used as an active ingredient biopesticide (Djatnika, 2012). Rhizobacteria have been used to control bacterial leaf blight disease in onion with Pantoea aglomerans strain C9-1, Pseudomomas fluorescens strain-A506 (Schwartz and Gent 2005), bacteriophage and acibenzolar-S-metil reduced disease severity in greenhouse and in the field (Lang et al, 2007).

The initial selection of rhizobacteria is done using the in vitro methods by looking at the barrier zone of rhizobacteria on agar plate. Rhizobacteria that do not produce compounds that produce zone barrier but are capable of competition and are able to increase plant resistance will not be detected. This research, to select indigenous rhizobacteria in plants can improve resistance to bacterial leaf blight disease and enhance plant growth in onions.

The research objectives are to: (1). Select isolates of indigenous rhizobacteria from plant healthy in endemic bacterial leaf blight disease that can enhance plant growth and resistance on onion to bacterial leaf blight disease, (2). Identification of molecular and Indol-3-acetic acid products indigenous rhizobacteria that can improve growth and resistance to bacterial leaf blight disease in onions.

\section{MATERIALS AND METHODS}

\section{Isolation of rhizobacteria from onion rhizospheres}

The rhizosphere soil samples were collected from healthy onion plants growing in areas of endemic bacterial leaf blight disease in East Java, Central Java, West Java, West Sumatra and North Sumatra. Soil samples were taken with a stratified sampling method, the soil placed in plastic bags and stored at $4 \mathrm{oC}$ in the laboratory of the Microbiology Faculty of Agriculture Andalas University. Ten grams of rhizosphere soil were placed in a $250 \mathrm{ml}$ conical flask and $90 \mathrm{ml}$ of steril distilled water was added to it. The flash was shaken for 10 minutes on a rotary shaker. One milliliter of suspension was added to a $10 \mathrm{ml}$ test tube and shaken for 2 minutes. Serial dilution techniques were performed upto 10-8 dilution. An aliquot $(0,1 \mathrm{ml})$ of this suspension was spread on the plates of Nutrient agar (NA) 
medium. Plates were incubated for 2 days at $280 \mathrm{C}$ to observe the colonies of bacteria. Well isolated single colonies were picked up and strored in an eppendorf with nutrient liquid medium add of $20 \%$ glycerol.

\section{Selection rhizobacteria to promote growth and induce resistance in onions}

One hundred and thirty eight rhizobacteria isolates were designated as treatment to onions. Onion bulbs (cultivar medan) from areas of endemic bacterial leaf blight disease that infested Xanthomonas axonopodis pv.allii in Alahan Panjang, Solok District, West Sumatra were rinsed in 2\% sodium hypochlorite for 30 seconds, washed with sterile water three times and dried for 15 minutes. Then the bulbs were treated with rhizobacterial isolates for 20 minutes and dried under shade. No treated bulbs isolates were designated as controls. The media of soil plus manure $(3: 1 \mathrm{v} / \mathrm{v})$ was sterilized by tyndalization. Onion bulbs were treated with rhizobacterial isolates then placed into a plastic pot. Fourth replications were carried out for each of the bacterial isolates. The observations conducted included the disease incubation period, the percentage of infected leaves, the percentage of seedlings symptom leaf blight disease, intensity of the disease using formula. Data was analyzed statistically by F-test the significance of differences between mean values was evaluated by DMRT (Duncan's Multiple Range Test).

$$
\begin{aligned}
& \mathrm{I}=\sum(\mathrm{n} 1 \times \mathrm{v} 1) \times 100 \% \\
& \mathrm{ZxN}
\end{aligned}
$$

Where; $\mathrm{I}=$ Intensity of disease, $\mathrm{n} 1=$ Total of leaves in each attach scale, $\mathrm{v} 1=$ Value of scale from attach scale, $\mathrm{N}=$ Total of leaves, $\mathrm{Z}=$ Value of scale the heigher. Value of scale from attach were rated based on the percent of symptoms they provided: 0 , no symptoms; $1(0-20 \%) 2(>20-40 \%) ; 3(>40-60 \%) ; 4(>60-$ $80 \%) ; 5(>80 \%$ ) (Balfas 1980 cit Habazar, 2005).

\section{IAA production}

Single colonies of bacterial culture were grown on LB liquid medium containing $0,1 \%$ DLTryphtophan and no DL-Tryphtophan. Bacterial cultures incubated in a refrigerated incubator shaker $180 \mathrm{rpm}$ for 48 hour in the dark. The bacterial cultures were centrifuged at $10.000 \mathrm{rpm}$ for $10 \mathrm{~min}$ at $4 \mathrm{o}$ C. Estimation of indole-3-acetic acid (IAA) in the supernatants was done using colorimetric assay (Akbari, et al. 2007)

\section{Molecular identification of rhizobacteria isolates}

\section{DNA Isolation, amplification and sequensing}

DNA isolation was started by growing pure culture in NB (Nutrient Broth) medium, then shaking at speeds of $160 \mathrm{rpm}$ for 24 hours, using DNA isolation methods based on Jeff Newman (http://lyco.lycoming.edu/-newman). Six ml of liquid culture of each of the isolates that had been cultured for 24 hours in a $2 \mathrm{ml}$ eppendorf tube, was then centrifuged for 3 minutes at a speed of 14,000 rpm to obtain pellets. Pellet was subsequently resuspended with $1 \times$ TE (Tris-EDTA) of $500 \mathrm{~mL}$ Then $40 \mathrm{~mL}$ of $10 \%$ SDS were added and $5 \mathrm{~mL}$ of proteinase $\mathrm{K}(10 \mathrm{mg} / \mathrm{mL})$. this was homogenized inverted and incubated for $1 \mathrm{~h}$ at $37^{\circ} \mathrm{C}$. After that it was added to the Phenol: Chloroform (PC) (24:24) as much as $1 \mathrm{x}$ volume, and centrifuged for 3 minutes at a speed of 14,000 rpm. Then take a supernatant and transfered to $2 \mathrm{ml}$ eppendorf tubes. Then added again the PC as much as the same volume and centrifuged for 5 minutes at a speed of 14,000 rpm. The supernatant was transferred into $1.5 \mathrm{ml}$ new eppendorf tubes. Then $1 / 10$ volume $3 \mathrm{M}$ sodium acetate and 0.6 volumes of isopropanol was added too until the DNA precipitated tube, then centrifuged for 1 minute at a speed of $14,000 \mathrm{rpm}$. The DNA pellet was washed with cold $70 \%$ ethanol in increments of $1 \mathrm{ml}$ for 30 seconds and dried using a heater block at a temperature of $550 \mathrm{C}$ for 5 minutes. After this the DNA pellet was suspended in 1xTE buffer as much as $100 \mathrm{~mL}$. Then the quality and quantity of DNA solution was analyzed with electrophoresis techniques. 
DNA extraction was amplified using primer combinations designed from the 16S rRNA gene sequence primer combinations used were 27F (5'-AGTTTGATCMTGGCTCAG-3') and 1525R (5'AAGGAGGTGWTCCARCC-3'). Results of sequencing used for the analysis of bacterial species by comparing the sequence obtained by gene sequences that have been deposited into public databases in silico using the BLAST program is done online at the web site the NCBI (National Center of Biotechnology formation) :http://www.ncbi.nlm.nih. gov/BLAST. Determination of the level of similarity using the program Clustal $\mathrm{W}$ version 1.8 is done online on the website http://www.ebi.ac.uk/serve/clustalw2.

\section{RESULTS}

\section{Isolation of rhizobacteria}

Rhizobacteria isolates from onion rhizospheres in five locations as disease-endemic areal 136 isolates were obtained (unpublished data). The type of rhizobacteria isolated depends on the area it is derived from and is influenced by biotic and non-biotic factors (Hayat et al, 2010; Ahemad and Kibret, 2014). The majority of isolates were obtained from locations in North Sumatra (53 isolates) followed by West Sumatra, West Java, East Java and Central Java with the number respectively 26, 20, 20 and 17 isolates (Table 1).

Table 1. Distribution of number isolates and physiologycal characters isolates from different areas of rhizosphere on onions

\begin{tabular}{lccccc}
\hline \multirow{2}{*}{ Origin of isolates } & \multirow{2}{*}{$\begin{array}{c}\text { Number of } \\
\text { isolates }\end{array}$} & \multicolumn{2}{c}{ Grams test } & \multicolumn{2}{c}{ Hypersentive test } \\
\cline { 3 - 6 } & 26 & 18 & 8 & 0 & 26 \\
\hline West Sumatera & 53 & 33 & 20 & 3 & 50 \\
North Sumatera & 20 & 2 & 18 & 0 & 20 \\
West Java & 17 & 8 & 9 & 3 & 14 \\
Central Java & 20 & 4 & 16 & 2 & 18 \\
East Java & 136 & 65 & 71 & 8 & 128 \\
\hline Total & & & &
\end{tabular}

Results of a Gram test of all isolates obtained $47.79 \%$ Gram-positive (65 isolates) and 52.21\% Gram-negative (71 isolates). To obtain rhizobacteria as biocontrol agents should use a hypersensitive reaction (HR) test. If the bacteria cause symptoms on the test plants (tobacco) which cause the symptoms of chlorosis in tobacco plants it means it cannot be used as a biocontrol agent candidate. According to Klement et al. (1990) plant pathogenic bacteria would induce the HR response. HR reaction is a rapid plant protection reaction against pathogens that are incompatible with non-host pathogens, the host with a non virulent pathogen or resistance host with pathogen virulent relationships. Isolation results obtained 8 isolates that had positive hypersensitivity reactions and these isolates were subsequently not used at the next test.

\section{Selection of potential rhizobacteria to promote plant growth and induce resistance in onions}

Ten of the 128 rhizobacteria isolates showed potential as a biocontrol agent showed a low intensity of symptoms and high growth and yield. Observation data from 128 isolates is unpublished. The selection of rhizobacteria isolates that increase resistance to bacterial leaf blight onion disease can be seen in Table 2. JTSH3.4 isolates are from East Jawa do not show symptoms of disease, otherwise isolates from East Java showed symptoms, such as $\mathrm{Wj} 1.1$, JM1.7 and $\mathrm{Jm} 2.11$ isolates. The isolates SM1SH3, L2Rz2.2 and JM2.11 effectively slow the appearance of disease symptoms. All isolates are recorded the incubation period of disease from 33.2 to 36.5 days after planting, with the effective suppression of disease incubation period of 63.16 to $72.4 \%$ (Table 2). The disease incubation period JM1.7, L5Rz3.2, L2Rz1.1, L5Rz2.1 and PP2Rz2 isolates are recorded from 19,5 to 30,5 days after planting, with the effective suppression of disease incubation period 37,18 to $67,77 \%$. 
Table 2. Ten isolates rhizobacteria potentially can be increase resistance to bacterial leaf blight in onions

\begin{tabular}{lcccc}
\hline Isolate Code & $\begin{array}{c}\text { Disase } \\
\text { Incubation } \\
\text { period (days) }\end{array}$ & $\begin{array}{c}\text { Effectivities } \\
\text { Incubation } \\
\text { period (\%) }\end{array}$ & $\begin{array}{c}\text { Intensity } \\
\text { disease } \\
(\%)\end{array}$ & $\begin{array}{c}\text { Effectivities } \\
\text { decrease of } \\
\text { disease (\%) }\end{array}$ \\
\hline JTSH3.4 & $*$ & $*$ & 0 & 100 \\
Wj1.1 & $30.00 \mathrm{~b}$ & 69.17 & $5.66 \mathrm{~b}$ & 87.94 \\
JM1.7 & $9.50 \mathrm{c}$ & 2.63 & $5.41 \mathrm{~b}$ & 88.48 \\
JM2.11 & $33.25 \mathrm{a}$ & 72.18 & $6.67 \mathrm{~b}$ & 85.74 \\
SM1SH3 & $36.50 \mathrm{a}$ & 74.66 & $9.60 \mathrm{~b}$ & 79.55 \\
PP2Rz2 & $30.50 \mathrm{~b}$ & 69.67 & $8.40 \mathrm{~b}$ & 82.11 \\
L5Rz2.1 & $22.00 \mathrm{c}$ & 57.95 & $4.50 \mathrm{~b}$ & 90.42 \\
L5Rz3.2 & $27.52 \mathrm{c}$ & 66.36 & $4.28 \mathrm{~b}$ & 90.88 \\
L2Rz1.1 & $12.40 \mathrm{~d}$ & 25.40 & $6.80 \mathrm{~b}$ & 85.52 \\
L2Rz2.2 & $12.25 \mathrm{~d}$ & 24.49 & $7.60 \mathrm{~b}$ & 83.81 \\
Control & $9.25 \mathrm{~d}$ & 0 & $46.95 \mathrm{a}$ & 0 \\
\hline
\end{tabular}

*No disease symptom

Means in column followed by different letter (s) are significantly different at $\mathrm{P}=0.05$ accoding to the DMRT

The ten selected isolates were infected by the disease with an intensity rang from 4.50 to $9.60 \%$, while the control is $46.95 \%$ and one isolate (JTSH3.4) does not show symptoms of the disease. Treatment with JM1.7 isolate demonstrated early symptoms at 9.5 days, further development of the disease is very slow to reach the intensity of disease $5.41 \%$, compared to the control which was $46.95 \%$. This indicates that rhizobacteria slowed disease progression. The incubation period is longer for the disease in the ten rhizobacteria isolates indicating high effectiveness of the treatment rhizobacteria. The isolate L2Rz2.2 had an incubation period of 12.25 days with $24.49 \%$ suppression effectiveness, compared with the control of 10.68 days. The next most four isolates in suppressing the disease are SM1SH3 (79.55\%), L2Rz2.1 (90.42\%), PP2Rz2 (82.11\%) and L5Rz1.1 (85.52\%).

\section{Selection of potential rhizobacteria to enhance plant growth of onion plants in pot}

Ten rhizobacteria isolates were selected to improve plant growth. Isolates L5Rz3.2, L2Rz1.1 and L2 Rz2.2 showed the highest plant height respectively $36.35,35.35$, and $34.59 \mathrm{~cm}$, whereas the untreated controls showed plant height reaching $30.38 \mathrm{~cm}$. isolates WJ1.1, SM3SH1, high L5Rz2.1 plant under control is $29,67-29,87$

Table 3. Days appear shoots, plant height, leaf number, number of tubers and weight of onion bulbs were introduced with rhizobacteria

\begin{tabular}{lccccc}
\hline Isolate Code & $\begin{array}{c}\text { Emerging } \\
\text { shoot(day) }\end{array}$ & $\begin{array}{c}\text { Plant } \\
\text { height }(\mathrm{cm})\end{array}$ & $\begin{array}{c}\text { Number of } \\
\text { leaf(sheet) }\end{array}$ & $\begin{array}{c}\text { Number } \\
\text { of bulb }\end{array}$ & $\begin{array}{c}\text { Weight of } \\
\text { Bulb/plant (g) }\end{array}$ \\
\hline JTSH3.4 & $5.33 \mathrm{a}$ & $42.17 \mathrm{a}$ & $32.45 \mathrm{c}$ & $7.75 \mathrm{~b}$ & $45.55 \mathrm{a}$ \\
Wj1.1 & $6.33 \mathrm{a}$ & $40.40 \mathrm{a}$ & $43,32 \mathrm{~b}$ & $8.00 \mathrm{ab}$ & $42,34 \mathrm{~d}$ \\
JM1.7 & $5.66 \mathrm{a}$ & $43.70 \mathrm{a}$ & $56.47 \mathrm{a}$ & $8.00 \mathrm{ab}$ & $53,46 \mathrm{a}$ \\
JM2.11 & $5,66 \mathrm{a}$ & $42.43 \mathrm{~b}$ & $38,33 \mathrm{c}$ & $9.33 \mathrm{a}$ & $40.15 \mathrm{~b}$ \\
SM1SH3 & $5,66 \mathrm{a}$ & $40.17 \mathrm{a}$ & $49,50 \mathrm{~b}$ & $10,30 \mathrm{a}$ & $41,56 \mathrm{~b}$ \\
PP2Rz2 & $5,66 \mathrm{a}$ & $42,13 \mathrm{a}$ & $38,50 \mathrm{c}$ & $9,00 \mathrm{a}$ & $43.45 \mathrm{ab}$ \\
L5Rz2.1 & $6.66 \mathrm{a}$ & $42.13 \mathrm{a}$ & $35,50 \mathrm{c}$ & $6.75 \mathrm{~b}$ & $46.76 \mathrm{a}$ \\
L5Rz3.2 & $6.33 \mathrm{a}$ & $41.10 \mathrm{a}$ & $38,50 \mathrm{c}$ & $7.50 \mathrm{~b}$ & $42.32 \mathrm{ab}$ \\
L2Rz1.1 & $5.66 \mathrm{a}$ & $42.73 \mathrm{a}$ & $43,50 \mathrm{~b}$ & $6.75 \mathrm{~b}$ & $54.35 \mathrm{a}$ \\
L2Rz2.2 & $6.66 \mathrm{a}$ & $41.73 \mathrm{a}$ & $46.50 \mathrm{~b}$ & $8.66 \mathrm{ab}$ & $44,80 \mathrm{ab}$ \\
Control & $6.66 \mathrm{a}$ & $36.80 \mathrm{~b}$ & $26.50 \mathrm{~d}$ & $6.33 \mathrm{c}$ & $18.55 \mathrm{c}$ \\
\hline
\end{tabular}

Means in column followed by different letter (s) are significantly different at $\mathrm{P}=0.05$ accoding to the DMRT 
Onion shoots with rhizobacteria isolates emerged sooner (5.33-6.66 days after planting) compared to the control (8,50 days after planting). this is caused by rhizobacteria producing plant growth regulators like IAA. Rhizobacteria isolates showing the highest number of leaf is 56.47 sheets with length $43.70 \mathrm{~cm}$ on JM1.7 isolate, while isolates SM1SH3, L5Rz3.2, L2Rz2.2 and Wj1.1 produced leaf numbers of $49.50,38.50,46.50$ and 43.23 respectively with lengths of 40,17, 41,10, 41,73 and $40,40 \mathrm{~cm}$ respectively compared to controls of 26,50 sheets and height $36,80 \mathrm{~cm}$.

The highest number of tubers per plant 10.30 bulbs and the weight $41,56 \mathrm{~g}$ came from a treatment with isolates $\mathrm{Jm} 1.7$. Treatments L5Rz3.2 and $\mathrm{Jm} 2.11$ isolates produced 7,50 tubers lower than the control 6,33 tubers, but the tuber weight L5Rz3.2 (42,32 g) and Jm2.11 (40.15 g) higher than control $18.55 \mathrm{~g} / \mathrm{plant}$. Low weight of tubers on the control caused the high intensity of the disease $46.92 \%$ (Table 2). High-intensity of a disease causes decreased plant growth so the tuber formed is not optimal. Bacterial leaf blight symptoms begin as small, chlorotic spots or shape lesions with water soaked margins. Lesions enlarge in to long chlorotic streaks and large greasy, waters soaked area that are most prominent on the flattened side of older leaves. Tip death and blighting of leaves reduce the plants photosynthetic area, resulting in a reduction in bulb size (Schwartz and Gent, 2005).

Characteristics and identification of rhizobacteria isolates that can improve plant growth and resistance on onion

\section{IAA Production}

The ten selected rhizobacteria indigenous isolates were tested for the quantitative estimation of IAA in media LB with L-tryptophan $(50 \mu \mathrm{g} / \mathrm{ml})$ and without L-tryptophan. Addition L-tryptophan, production of IAA height from without L-tryptophan. With the addition L-tryptophan the production of IAA range between 1.70-15.28 $\mu$ g.mL-1, conversely no addition L-tryptophan 1.1-8.9 $\mu$ g.ml-1 (Fig.1). The production of IAA was relatively high concentration in isolate of Pseudomonas sp (15.3 $\mu \mathrm{g} . \mathrm{ml}-1)$, followed by Bacillus sp (15.0 $\mu \mathrm{g} . \mathrm{ml}-1)$ and Bacillus sp (12.4 $\mu \mathrm{g} . \mathrm{ml}-1)$ respectively. The height of IAA production on Pseudomonas sp (JM1.7) and Bacillus sp (L2Rz1.1) isolates can enhance plant growth (Table 3). Production of high levels of IAA by Pseudomonas sp is a general characteristic of genera of Pseudomonas, as similar high levels of IAA production were recorded by Ahmad et al. (2014). The physiologically most active auxin in plant is IAA, which is known to stimulate both rapid increases in cell elongation and cell division/differentiation responses in plant.

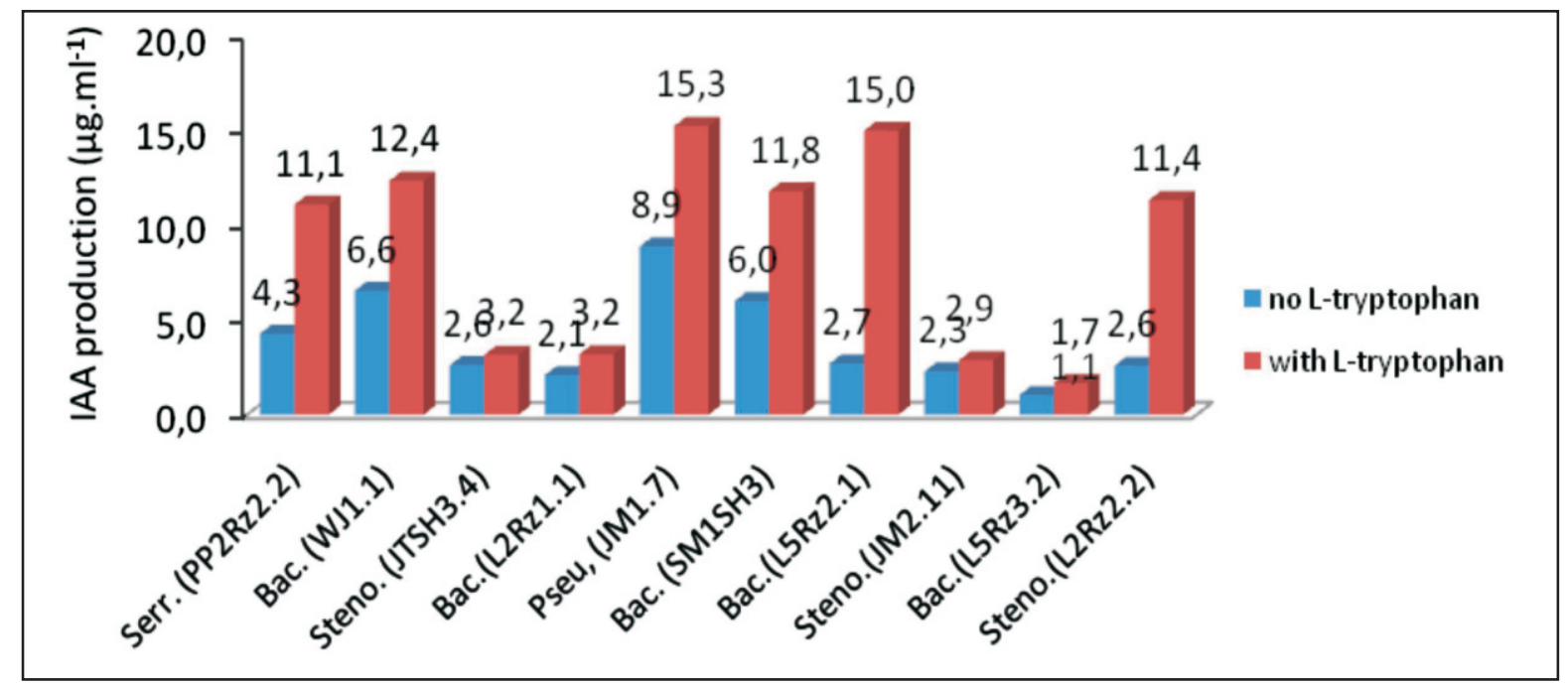

Figure 1. Production of IAA by selected rhizobacteria isolates grown on LB medium with no and addition L-tryptophan 
In the present investigation 10 isolates rhizobacteria, quantitative analysis of IAA production was made on one Pseudomonas isolate, five Bacillus isolates, three Stenotrophomonas isolates and one Serratia isolate. IAA is the most common and best characterized phytohormone. It has been estimated that $80 \%$ of bacteria isolates from rhizospheres can produce the plant growth regulator IAA (Patten and Glick, 1996). Similar trends of IAA production with the increasing concentration of tryptophan was also reported by Barazani and Friedman (2000) and Ahmad et al. (2014). The production of IAA was found dependent upon bacterial isolates and addition L-tryptophan. Such findings may have direct practical applications, although intrinsic ability of bacteria to produce IAA in the rhizosphere depends on availability of precursors and uptake of microbial IAA by plant (Arshad and Frankenberger,1993).

\section{Identification molecular of rhizobacteria}

Product of amplification 16S rRNA gene was selected rhizobacteria using universal primers $27 \mathrm{~F} / 1525 \mathrm{R}$. The results of the analysis of $16 \mathrm{~S}$ RNA gene sequences can be seen in Table 4 . The similarity of sequences of rhizobacteria isolates with isolates that have been deposited in GenBank can be seen through an analysis using the BLAST program. BLAST will match the base sequence of locally or only in certain areas of overall sequence of bases. The result of BLAST program is done online at the web site the NCBI can be seen in Table 4.

Results of BLAST program can determine the percentage of similarity of an isolate with existing data in GenBank. DNA from three isolates of rhizobacteria have similarities with the genera Stenotrophomonas ie, isolates JM2.11, JTSH3.4, and L2Rz2.2 with different similarity percentages. DNA from five isolates of rhizobacteria has similarities with the genera Bacillus with different similarity percentages ie. SM1SH3, WJ1.1, L2Rz1.1, L5Rz2.1 and L5Rz3.2 . DNA from JM1.7 isolates has similarity with the genus Pseudomonas with similarity percentages 99\%, and PP2Rz2 isolates has similarity with genus Serratia with similarity percentages 99\% (Table 4).

Table 4. The result of search sequences of $16 \mathrm{~S}$ rRNA gene of selected rhizobacteria with similarity species on found in GenBank

\begin{tabular}{|c|c|c|c|}
\hline Code isolate & Code acces & Description & $\begin{array}{c}\text { Similarity } \\
(\%)\end{array}$ \\
\hline JTSH3.4 & FJ950686.1 & $\begin{array}{l}\text { Stenotrophomonas sp. d } 4616 \mathrm{~S} \text { ribosomal RNA } \\
\text { gene, partial sequence }\end{array}$ & 80 \\
\hline Wj1.1 & EU584531.1 & $\begin{array}{l}\text { Bacillus sp. cp-h3 16S ribosomal RNA gene, } \\
\text { partial sequence }\end{array}$ & 98 \\
\hline JM1.7 & EU194335.1 & $\begin{array}{l}\text { Pseudomonas geniculata strain XJUHX-19 16S } \\
\text { ribosomal RNA gene, partial sequence }\end{array}$ & 99 \\
\hline JM2.11 & AY880273.1 & $\begin{array}{l}\text { Stenotrophomonas maltophilia strain M5-2 16S } \\
\text { ribosomal RNA gene, partial sequence }\end{array}$ & 70 \\
\hline SM1SH3 & AB508850.1 & $\begin{array}{l}\text { Bacillus pumilus gene for } 16 \mathrm{~S} \text { ribosomal RNA, } \\
\text { partial sequence, strain: TSH } 22 \mathrm{w}\end{array}$ & 94 \\
\hline PP2Rz2 & AY514434.1 & $\begin{array}{l}\text { Serratia marcescens strain N2.4 16S ribosomal } \\
\text { RNA gene, partial sequence }\end{array}$ & 99 \\
\hline L5Rz2.1 & NC008600.1 & Bacillus thuringiensis str. Al Hakam, & 99 \\
\hline L5Rz3.2 & NC012472.1 & Bacillus cereus $03 \mathrm{BB} 102$, complete genome & 99 \\
\hline L2Rz1.1 & EU834245.1 & $\begin{array}{l}\text { Bacillus cereus strain DS16 16S ribosomal } \\
\text { RNA gene, partial sequence }\end{array}$ & 98 \\
\hline L2Rz2.2 & AJ131114.1 & $\begin{array}{l}\text { Stenotrophomonas maltophilia strain LMG } \\
\text { 957, 16S ribosomal RNA, partial }\end{array}$ & 99 \\
\hline
\end{tabular}


Ten isolates of rhizobacteria was elected as a biocontrol agent on onion crop is only classified into four genera of bacteria are Pseudomonas, Bacillus, Stenotrophomonas and Serratia. Genus of Bacillus are Gram-positive and members of Bacillus species are able to form endospores and hence survive under adverse conditions, as many reports on their growth promoting activity reveal (Zehnder et al, 2001; Vessey, 2003). Genus Pseudomonas are Gram-negative, most abundant genus in the rhizosphere and PGPR activity (Hayat, et al, 2010).

\section{CONCLUSIONS}

The beneficial effect of rhizobacteria isolates include direct plant growth promotion, biological control and inducing systemic resistance in host plant. From the experiments conducted it can be concluded that the Pseudomonas sp and Bacillus sp isolated from the rhizosphere of onion were able to increase growth and induce systemic resistance to bacterial leaf blight disease on onions.

\section{REFERENCES}

Alvares, A.M., Buddenhagen, I.W., Buddenhagen,E.S. and Domen, H.Y. 1978. Bacterial blight of onion, a new disease caused by a Xanthomonas sp. phytopathology. 68:1132-1136.

Ahemad, M. and M. Kibret. 2014. Mechanisms and applications of plant growth promoting rhizobacteria. J. of King Saud University-Science. 26: pp1-20

Ahmad F. I., I. Ahmad I, and Khan MS. 2005. Indole Acetil acid production by the indigenous isolates of Azotobacter and Flourescent Pseudomonas in the presence and absence of tryptophan. J..Biology Turkey. 29: pp 29-34.

Arshad, M. and Frankenberger, Jr.W.T. 1993. Microbial production of plant growth regulators. In Blaine F. and metting, Jr. (Eds) Soil Microbial Ecology. Marcel and Dekker, Inc. New York, pp307-347.

Barazani, O. and Friedman, J. 2000. Effect of exogeneously applied L-tryptophan on allelochemical activity of plant growth promoting rhizobacteria (PGPR). J. Chem. Ecol. 26, 343-349.

Brimecombe,M.J., F.A. Leij. and J.M. Lynch.2001. The effect of root exudates on rhizospheremicrobial communities. I. The Rhizosphere. Biochemistry and organic subatance at soil-plant interface. Maecell Dekker. New York. pp 95-140

Chakraborty,U., B.N. Chakraborty, A.P.Chakraborty, K. Sunar and P.L. Dey. 2013. Plant growth promoting rhizobacteria mediated improvement of health status of tea plants. Indian $\mathrm{J}$ of Biotechnology. Vol 12, January, pp 20-31

Dajtnika, I. 2012. Seleksi bakteri antagonis untuk mengendalikan layu fusarium pada tanaman Phalaenopsis. J. Hortikultura vol 22 (3): 276-284

Fadhli. 2005. Uji tingkat serangan penyakit hawar daun bakteri pada beberapa varietas bawang merah di Kecamatan Lembah Gumanti Kabupaten Solok. Skripsi fakultas Pertanian Unand. Padang

Gent, D.H., J.M. Lang, H.F. Schwartz. 2005. Epiphytic survival of Xanthomonas axonopodis pv.allii and $\mathrm{X}$. axonopodis pv.phaseoli on leguminous hosts and onion. The American Phytopathological Society. Plant Disease, 89(6):558-564

Gent, D. H. And H. F. Schwartz. 2005. Effect of Nitrogen fertilization and Seed contamination on epiphytic populations of Xanthomonas axonopodis pv.alii and development leaf blight of onion. Online. Plant Health Progress doi: 10.12094/PHP-2005-0331-010-RS.

Habazar, T. 2006. Pengenalan penyakit hawar daun bakteri oleh Xanthomonas axonopodis pv.allii pada tanaman bawang merah. Makalah dalam apresiasi penanggulangan OPT tanaman sayuran. 3-6 Oktober di Nganjuk.

Hayat, R.,S. Ali, U. Amara, R. Khalid and I. Ahmed. 2010. Soil beneficial bacteria and their role in plant growth promotion. Ann. Microbiology. DOI 10.1007/s13213-010-0117-1. 
Husna, R. 2006. Tingkat serangan penyakit hawar daun bakteri disebabkan oleh Xanthomonas axonopodis pv.allii pada beberapa jenis tanaman bawang (Allium sp). Skripsi. Fakultas Pertanian Unand.Padang

Khan, M.S. 2006. Screening of Free-living rhizospheric bacteria for their multiple plant growth promoting activities. Microbio J. 163:173-181

Klement, Z., K. Rudolph, D.C. Sand. 1990. Methods in Phytobacteriology. Budapest: Akademiai Kiado.

Kloepper J. W. and M. N. Scroth. 1981. Relationship of in vitro antibiosis of plant growth promoting rhizobacteria to plant growth and the displacement of root microflora. Phytopathology 71: 10201024

Lang, J. M., D.H. Gent, H.F. Schwartz. 2007. Management of xanthomonas leaf blight of onion with bacteriophages and a plant activator. The American Phytophatology Society. Plant Disease.91(7): 871-878

Lugtenberg, B. and F.Kamilova, 2009. Plant growth promoting rhizobacteria. Annual Rev. Microbiology. 63:541-556

Manoharachary, C. and K.G. Mukerji. 2006. Rhizosphere Biology- An Overview. In Soil Biology. Springer-Verlag Berlin Heidelberg. (7). 1-15p

Nelson, L.M. 2004. Plant Growth promoting rhizobacteria (PGPR): prospect for new inoculants. Online. Crop management doi: 10.1094/CM-2004-0301-05-RV.

Patten, C.L and B.R Glick.1996. Bacterial biosynthesis of indole-3-acetic acid. Canadian J. Microbiology. 42; 207-220

Patten, C. and B. Glick. 2002. Role of Pseudomonas putida indolacetic acid in development of the host plant root system. Appl. Environment Microbiology. 68;3795-3801.

Paulraj, L. and L.W. O'Garro. 1993. Leaf blight of onion in Barbados caused by xanthomonas campestris. Plant Disease. 86. 330-335

Roumagnac, P., Gagnevin, L., Gardan, L., Sutra, L., Manceau, C., Dickstein, E. R., Jones, J. B., Rott, P., dan Pruvost, O. 2004. Polyphasic characterization of Xanthomonads isolated from onion, garlic and welsh onion (Allium spp) and their relatedness to different Xanthomonas species. Int J. Syst. Evol. Microbiology 54:15-24.

Singh, G and K.G. Mukerji. 2006. Root Exudates as Determinant of Rhizospheric Microbial Biodiversity. In Soil Biology. Springer-Verlag Berlin Heidelberg (7); 39-53pp

Sutariati,G.A.K and A. Wahab. 2010. Isolasi dan uji kemampuan rizobakteri indigenous sebagai agensia pengendali hayati penyakit tanaman cabai. J. Hortikultura. Vol 20 (1):86-95

Taufiq,M.A., A. Wahab dan S.H.Hidayat. 2010. Mekanisme ketahanan terinduksi oleh plant growth promoting rhizobacteria (PGPR) pada tanaman cabai terinfeksi cucumber mozaik virus (CMV). J. Jortikultura. Vol 20 (3):274-283

Van Loon, L.C. and P.A.H.M Bakker. 2003. Signalling in Rhizobacteria-Plant Interactions. Ecological studies. Vol 168. Springer-Verlag Berlin Heidelberg. 297-330

Van Loon,L.C., PAHM. Bakker and CMJ. Piterse. 2002. Prospect and challenges for practical application of rhizobacteria-mediated induced systemic resistance. In Induced Resistance in Plants Against Insects and Diseases. IOBC/wprs Bull. Vol 25 (6). 75-82pp

Vessey, J. K. 2003. Plant growth promoting rhizobacteria as biofertilizers. Plant Soil. 255:571-586 